\title{
Solar radiation-driven decay of cyanophage infectivity, and photoreactivation of the cyanophage by host cyanobacteria
}

\author{
Kai Cheng ${ }^{1,2,3}$, Yijun Zhao ${ }^{2}$, Xiuli $\mathrm{Du}^{2}$, Yaran Zhang ${ }^{2}$, Shubin $\mathrm{Lan}^{2}$, Zhengli Shi ${ }^{1, *}$ \\ ${ }^{1}$ State Key Laboratory of Virology, Wuhan Institute of Virology, Chinese Academy of Sciences, Wuhan 430071, PR China \\ ${ }^{2}$ Hubei Key Laboratory of Urban Water, Environmental Ecology, Central China Normal University, Wuhan 430079, PR China \\ ${ }^{3}$ Graduate School of Chinese Academy of Sciences, Beijing 100039, PR China
}

\begin{abstract}
Cyanophage PP (isolated from Plectonema boryanum and Phormidium foveolarum and named after the respective first letters of its 2 hosts) is a short-tailed, icosahedral-shaped, and doublestranded DNA virus and can be frequently detected with a high abundance and activity in many eutrophic lakes in Wuhan City, PR China. To understand how the virus survives solar UV-B damage, we examined the decay of cyanophage PP induced by solar UV-B radiation and the photoreactivation repair by host cyanobacteria, on $1 \mathrm{~d}$ in each of the 4 different seasons throughout a year. The UV-B transparent or non-transparent bag containing the cyanophage PP was exposed to sunlight at different water depths and was collected at varying time points. The collected sample was treated with or without radiation of a photoreactivating wavelength $(300$ to $500 \mathrm{~nm}$ ). The decay ratio (here designated as the percentage of infectivity lost) for cyanophage PP from all samples caused by UV-B radiation ranged from 29.8 to $92.1 \%$. Season and water depth were the main factors influencing the decay ratio, while long exposure time had less effect. The repair ratio (here designated as the percentage of revived infectivity by photoreactivation) for cyanophage PP reached a maximum during the first 1 to $3 \mathrm{~h}$ of exposure, at all depths. The maximum repair ratios of photoreactivation for each of the decayed samples, ranging from 7 to $59 \%$, were negatively correlated with the decay ratio. In most cases, the repair ratio of photoreactivation reached a maximum in the first $4 \mathrm{~h}$. Our results indicate that solar UV-B radiation may decrease the infectivity of cyanophage PP in shallow freshwater bodies in an extraordinarily fast and effective manner, whereas rapid photoreactivation may contribute to balancing the rapid phototoxicity.
\end{abstract}

KEY WORDS: Cyanophage PP · UV-B · Decay ratio $\cdot$ Photoreactivation repair ratio

\section{INTRODUCTION}

Cyanophages play an important role in aquatic ecosystems, such as maintaining the concentration of the host, promoting cyanobacteria diversity through gene transfer, and decreasing the transfer of organic matter and nutrients to higher trophic levels (Fuhrman 1999, Weinbauer 2004, Tucker \& Pollard 2005).

To understand the role of cyanophages in the ecosystem, we first must understand their behavior in water bodies. It is known that the viruses enter the ecosystem by lysing the host, and leave the system by protozoan grazing, attachment to labile colloids, degrada- tion by heat-labile and high-molecular-weight dissolved material, and decay by the ultraviolet component of solar radiation (Wommack \& Colwell 2000). Currently, solar UV radiation, especially UV-B, is considered to be the dominant factor in controlling viral infectivity in seawater and could contribute a decay rate of $0.75 \mathrm{~d}^{-1}$ to the overall cyanophage decay (Noble \& Fuhrman 1997, Garza \& Suttle 1998). However, it is known that there is a high abundance and activity of cyanophages at the water surface. Therefore, the maintenance of virus infectivity despite solar UV damage may rely on some repair mechanism. There is evidence indicating that photoreactivation repair plays an important role in 
restoring the infectivity of viruses and may compensate for up to $52 \%$ of the sunlight-damaged virus (Weinbauer et al. 1997). Photoreactivation has been studied extensively in bacteriophages and natural virus communities in seawater. However, there have been no reports regarding photoreactivation in UV-Bdamaged cyanophages, especially cyanophages in freshwater. In addition, researchers have previously documented that viral abundance can change over a very short time (Bratbak et al. 1990), implying a rapid rate of virus production and removal in aquatic ecosystems (Noble \& Fuhrman 2000). Thus, it is important to understand how UV damage and photoreactivation contribute to the rapid changes in cyanophage levels.

In our previous work, we found a high abundance and activity of one type of cyanophage in several eutrophic lakes in Wuhan, in the Hubei Province of China. This cyanophage can infect Plectonema boryanum and Phormidium foveolarum and was named cyanophage PP (after the respective first letters of its 2 hosts). This virus was characterized as a shorttailed, icosahedral-shaped, double-stranded DNA virus, $52 \mathrm{~nm}$ in size and with a genome of $30 \mathrm{kbp}$ (Zhao et al. 2002, Guo et al. 2003). In this study, we investigated solar UV damage in cyanophages and photoreactivation repair in the damaged virus in a shallow freshwater lake, across the 4 seasons of a year. Our results indicate that rapid decay of cyanophages induced by solar UV radiation can be compensated for by rapid photoreactivation by host cyanobacteria. These results may help to understand the fluctuations in levels of cyanophages in freshwater.

\section{MATERIALS AND METHODS}

Cyanobacterium and cyanophage. The cyanobacterial strain, the axenic Plectonema boryanum IU594, originally obtained from the Freshwater Algae Collection of the Institute of Hydrobiology, Chinese Academy of Sciences, was cultured in AA medium (Richard 1988 ) at $28^{\circ} \mathrm{C}_{i} 1500$ Lux white light was provided by a white fluorescent tube (Osram L 18W/160) and the photocycle was set to $16 \mathrm{~h}$ light: $8 \mathrm{~h}$ dark.

Cyanophage PP was prepared as follows: 21 of Plectonema boryanum IU594 culture $\left(10^{7}\right.$ cells $\left.\mathrm{ml}^{-1}\right)$ was concentrated to $200 \mathrm{ml}$ by centrifugation at $5000 \times g$ for $5 \mathrm{~min}$, and then inoculated with $10 \mathrm{ml}$ of $10^{8} \mathrm{PFU}$ $\mathrm{ml}^{-1}$ cyanophage PP (PFU, plaque-forming unit). After incubation at $28^{\circ} \mathrm{C}$ for $24 \mathrm{~h}$, the cyanobacteria were completely lysed. Chloroform (10\%) was then used to precipitate the host cell debris, and the supernatant was stored at $4^{\circ} \mathrm{C}$ (Fox et al. 1976).

Sample treatment in the field. The sample treatment site $\left(30^{\circ} 32.771^{\prime} \mathrm{N}, 114^{\circ} 21.963^{\prime} \mathrm{E}\right)$ was set to $80 \mathrm{~m}$ from the bank of Donghu Lake, Wuhan, PR China. Donghu Lake is located inside the city of Wuhan and has suffered from eutrophication since 1980. The viral samples were filtered through a $0.45 \mu \mathrm{M}$ filter before treatment periods as follows: spring, from 08:30 to 17:30 h on March 6, 2004; summer, from 08:30 to 17:30 h on July 7, 2004; autumn, from 08:30 to $17: 30 \mathrm{~h}$ on October 7, 2004; and winter, from 08:30 to $16: 00 \mathrm{~h}$ on January 3, 2005. All sampling days were sunny. During the day of experiments, solar UV-B intensity was measured hourly with a VLX-3W radiometer (Vilber Lourmat) at $320 \mathrm{~nm}$. The Secchi disk depth of the sampling site was measured via a $25 \mathrm{~cm}$ Secchi transparency dish, and the surface water temperature was measured directly by a mercury thermometer at midday.

The tested group was treated in the following way: triplicate $2.5 \mathrm{ml}$ cyanophage PP suspensions $\left(10^{6} \mathrm{PFU}\right.$ $\mathrm{ml}^{-1}$ ) were placed in small polyethylene (PE) bags in which UV-B and UV-A were attenuated by 9 and $5 \%$, respectively, and the bags were then lowered vertically to water depths of 20,70 , and $120 \mathrm{~cm}$, respectively (Garza \& Suttle 1998). In the control group, cyanophage PP was placed in an anti-UV windscreen membrane bag (Model 3535, provided by 3M company), in which UV-B was attenuated by $>99 \%$ and incubated in the same way as the tested group. In spring, summer, and autumn, samples were exposed to sunlight from 08:30 to $17: 30 \mathrm{~h}$, and collected after 3,6, and $9 \mathrm{~h}$ exposure. In winter, samples were exposed to sunlight from 08:30 to 16:00 $\mathrm{h}$, and collected after 3, 6, and $7.5 \mathrm{~h}$ exposure.

Measurement and calculation of the decay ratio of cyanophage PP and the host's photoreactivation ratio (repair ratio). The amount of decay was inferred from the difference between the titer of cyanophage PP with or without exposure to solar UV-B. The decay ratio (the percentage of infectivity lost) was denoted as the ratio (\%) between the amount of decay and the titer of the initial cyanophage PP in the experiment. The photoreactivating level was inferred from the difference between the titer of cyanophage PP, which was exposed to solar UV-B with or without photoreactivation treatment. The repair ratio (the percentage of revived infectivity by photoreactivation) was denoted as the ratio (\%) between the amount of photoreactivation and amount of decay.

The titer of cyanophage PP was measured under red light $(>610 \mathrm{~nm})$, which prevents photoreactivation (wavelengths from 300 to $500 \mathrm{~nm}$ ) (Sinha \& Hader 2002) and which was necessary for the infection of hosts by cyanophage PP and for forming the PFU in the plaque assay (Zhao et al. 2002). Red PE cellophane was used to screen the light from the white fluorescent tube (Osram L 18W/160), providing red light. Under 
red light conditions, each of the $0.1 \mathrm{ml}$ tested group and control group samples were quickly mixed with $0.9 \mathrm{ml}$ host cells $\left(>10^{7}\right.$ cells $\mathrm{ml}^{-1}$ ). The mixture was adsorbed for $1 \mathrm{~h}$, then serially diluted and used for the plaque assay in the plate (Suttle 1993). To study the decay ratio from sunlight, the plate was cultured in red light until the formation of plaques was observed. For examination of photoreactivation effects, the plate was cultured under the anti-UV windscreen membrane (Osram L 18W/160, 1500 Lux) for 1, 2, 3, 4, and $24 \mathrm{~h}$, and then moved to red light to stop the photoreactivation. Finally, titers of cyanophage were recorded and used for analysis. Each sample was tested in triplicate.

Plaque assay. A volume of $900 \mu \mathrm{l}$ host cell concentrate $\left(108\right.$ cells $\left.\mathrm{ml}^{-1}\right)$ was combined in a sterile microfuge tube with $100 \mu \mathrm{l}$ of sample to be assayed. The MOI (multiplicity of infection) was set to be $<1: 1000$, and the mixture was mixed quickly by gentle vortexing in order to prevent multiple infections of a single filament. The mixture was maintained without shaking for $40 \mathrm{~min}$ for adsorption. Following adsorption, the sample was added to a tube containing $2 \mathrm{ml}$ of molten top agar and vortexed, and the contents were quickly poured onto the bottom agar. After $30 \mathrm{~min}$, the plates were inverted and incubated until the plaques were clear enough to be counted.

\section{RESULTS}

\section{Environmental factors at the sampling site}

Donghu Lake in Wuhan is the largest inner-city lake in PR China $\left(27.8 \mathrm{~km}^{2}\right)$ and has an average depth of about $220 \mathrm{~cm}$. In the past $20 \mathrm{yr}$, like many other city lakes in PR China, Donghu Lake has suffered greatly from eutrophication. Its Secchi disk depth ranges from 70 to $80 \mathrm{~cm}$ during the spring and winter and from 40 to $50 \mathrm{~cm}$ in the summer and autumn (Table 1). On the 4 sampling days, the strongest solar UV-B intensity was measured in the summer, then the autumn, then the spring, and the weakest was in the winter. Here, we gave the data of solar UV320 as it falls to the UV-B wavelength spectrum (280 to 320) (Fig. 1).

Table 1. Water temperature, Secchi disk depth, and maximum intensity on sampling days

\begin{tabular}{|lccc|}
\hline Date & $\begin{array}{c}\text { Water } \\
\text { temperature } \\
\left({ }^{\circ} \mathrm{C}\right)\end{array}$ & $\begin{array}{c}\text { Water } \\
\text { transparency } \\
(\mathrm{cm})\end{array}$ & $\begin{array}{c}\text { Maximum sun- } \\
\text { light intensity } \\
(\text { Lux })\end{array}$ \\
\hline March 6, 2004 (spring) & 10 & 70 & 75000 \\
July 7, 2004 (summer) & 29.5 & 47 & 88800 \\
October 7, 2004 (autumn) & 21 & 42 & 64200 \\
January 3, 2005 (winter) & 9 & 77 & 50800 \\
\hline
\end{tabular}

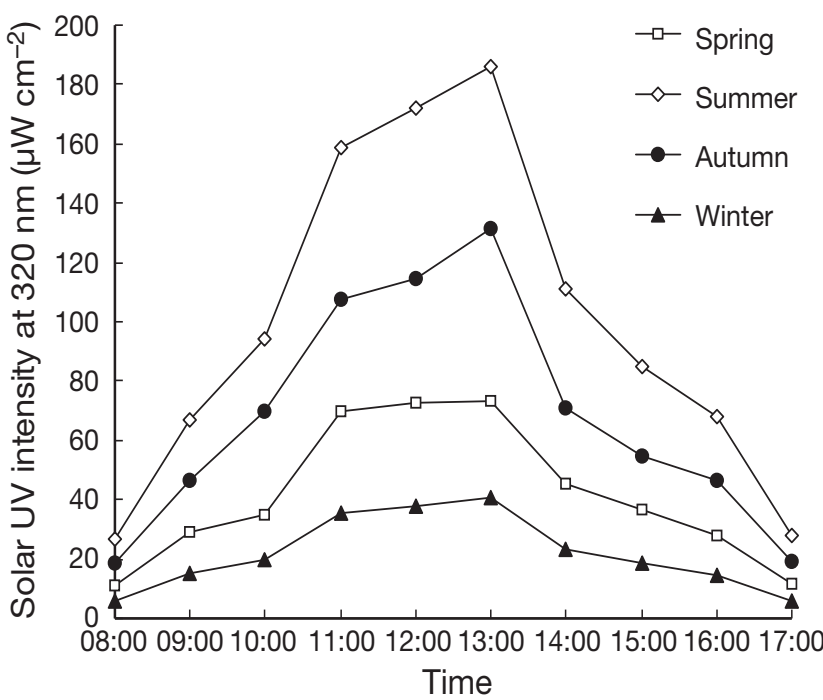

Fig. 1. Solar UV320 intensity in the field on sampling days (see Table 1 for dates)

\section{UV-B-induced decay ratio of cyanophages and the repair ratio of photoreactivation by host cyanobacteria}

The UV-B in solar radiation had a strong effect on cyanophage PP (Table 2), and the decay ratio varied from 45.19 to $90.2 \%$ for a full day of radiation. Analysis of variance indicated that both season and water depth, which was closely related to the Secchi disk depth, had a significant effect on the decay ratio $(p<$ 0.01 for both). In contrast, exposure time had less of an effect on the decay ratio $(p=0.49)$. This indicated that the decay of cyanophages occurred immediately after exposure to solar radiation. To understand what occurred in the first $3 \mathrm{~h}$ of exposure, an additional sampling time point was added on the autumn and winter study days. The results confirmed that there was little difference between 1 and $3 \mathrm{~h}$, especially at depths of 20 and $70 \mathrm{~cm}$ (Table 2).

The UV-B-decayed cyanophages could be repaired by host cyanobacteria. For all the tested samples, the repair ratio increased rapidly in the first $4 \mathrm{~h}$, but did not increase significantly in the next $20 \mathrm{~h}$ (see Table 3). This indicated that most of the photoreactivation occurred in the first $4 \mathrm{~h}$ and that maximum repair ratios probably existed in each case (Fig. 2). Because the maximum decay ratio of cyanophages occurred within $3 \mathrm{~h}$, for simplification, here we presented only the data of the repair ratio for cyanophage PP which was exposed to solar UV radiation for $3 \mathrm{~h}$ at a depth of $70 \mathrm{~cm}$ (Fig. 2). The observed maximum repair ratios varied with the decay ratio of 
Table 2. Decay ratio (mean \pm SE) of cyanophages induced by UV-B in the 4 seasons $(\mathrm{n}=3)$. -: no sampling at this time point

\begin{tabular}{|lccccc|}
\hline \multirow{2}{*}{$\begin{array}{l}\text { Sunlight expo- } \\
\text { sure time (h) }\end{array}$} & \multirow{2}{*}{$\begin{array}{c}\text { Water } \\
\text { depth }(\mathrm{cm})\end{array}$} & Spring & Summer & Autumn & Winter \\
\cline { 3 - 6 } 1 & 20 & - & - & $54.67 \pm 7.4$ & $65.69 \pm 1.0$ \\
1 & 70 & - & - & $41.80 \pm 12.2$ & $64.71 \pm 2.0$ \\
1 & 120 & - & - & $29.81 \pm 17.1$ & $61.11 \pm 2.0$ \\
3 & 20 & $83.33 \pm 3.9$ & $92.10 \pm 1.4$ & $57.22 \pm 4.1$ & $67.32 \pm 1.5$ \\
3 & 70 & $67.80 \pm 6.4$ & $73.50 \pm 4.7$ & $44.11 \pm 2.6$ & $60.78 \pm 2.0$ \\
3 & 120 & $41.67 \pm 2.5$ & $65.10 \pm 7.6$ & $33.33 \pm 6.3$ & $56.86 \pm 1.7$ \\
6 & 20 & $88.47 \pm 0.1$ & $88.30 \pm 3.2$ & $48.33 \pm 5.9$ & $69.61 \pm 9.8$ \\
6 & 70 & $76.67 \pm 3.3$ & $60.89 \pm 5.7$ & $47.78 \pm 4.3$ & $65.69 \pm 9.8$ \\
6 & 120 & $66.33 \pm 4.1$ & $60.90 \pm 5.8$ & $40.33 \pm 6.2$ & $64.05 \pm 4.1$ \\
7.5 & 20 & - & - & - & $69.28 \pm 4.1$ \\
7.5 & 70 & - & - & - & $66.99 \pm 3.0$ \\
7.5 & 120 & - & - & - & $67.32 \pm 2.5$ \\
9 & 20 & $90.20 \pm 1.4$ & $87.60 \pm 3.2$ & $49.63 \pm 2.3$ & - \\
9 & 70 & $78.67 \pm 4.1$ & $67.20 \pm 4.1$ & $49.63 \pm 3.4$ & - \\
9 & 120 & $48.87 \pm 4.2$ & $65.31 \pm 3.5$ & $45.19 \pm 6.8$ & - \\
\hline
\end{tabular}

time to reach the limit is relatively short; for example, the decay ratio in winter and autumn reached the maximum in only $1 \mathrm{~h}$ at a depth of 20 to $70 \mathrm{~cm}$. One explanation for this phenomenon is that the UV radiation is rapidly balanced by some resistance mechanisms. The sequence, structure, and genomic size of the DNA may contribute to the sensitivity and the resistance to damage (Garza \& Suttle 1998, Wilhelm et al. 1998, Kellogg \& Paul 2002, Jacquet 2003).

A natural logarithmic function has been widely used to calculate an hour's decay (denoted as the decay rate) from a whole day's decay rate (Wommack et al. 1996, Garza \& Suttle 1998, Wilhelm et al. 1998). Typically, the result ranged from unde-

cyanophages. In general, there was a significant negative correlation between the maximum repair ratio and the decay ratio $(\mathrm{p}<0.01)$.

\section{DISCUSSION}

Our results demonstrated that the decay of phage infectivity was correlated to the intensity of solar radiation (e.g. high transparency, shallow water depth, and high-intensity solar radiation). Of the abovementioned factors, depth of penetration into the water was the key factor in influencing the UV damage to aquatic organisms (Regan et al. 1992, Wommack et al. 1996, Hader \& Sinha 2005). Although a previous report showed that the effective depth for UV damage in viruses ranges from $200 \mathrm{~m}$ in clear seawater to about $2 \mathrm{~m}$ in turbid water, the decay ratio decreases rapidly to approximately 10 to $20 \% \mathrm{~h}^{-1}$ at a depth of 1 to $2 \mathrm{~m}$ (Cottrell \& Suttle 1995). We found that UV-B radiation led to a decay ratio of 29.8 and $61.1 \%$ over $1 \mathrm{~h}$ at a depth of $120 \mathrm{~cm}$ in autumn and winter, respectively, which was much higher than the published data (Cottrell \& Suttle 1995). In addition, we should also note that the high decay ratio occurred at a depth of 70 to $120 \mathrm{~cm}$, for which the Secchi disk depth ranged from 42 to $77 \mathrm{~cm}$ on the sampling day. Thus, it would appear to be difficult for cyanophages (and other virioplankton) to survive in shallow lakes such as Donghu Lake (especially in winter, when the Secchi disk depth is high).

Our results clearly demonstrated that a limit in the decay ratio existed, ranging from ca. $90 \%$ in the summer to ca. $45 \%$ in the autumn at a depth of $120 \mathrm{~cm}$. The tectable in the winter to ca. $0.335 \mathrm{~h}^{-1}$ in the summer in surface seawater (Garza \& Suttle 1998). However, it appears that this calculation cannot be applied to our experimental data. Our data demonstrated that $1 \mathrm{~h}$ is sufficient to reach the limit of UV-induced damage in subsurface water. This means that the correct decay rate could only be deduced from a decay rate within the range of the first hour; otherwise, underestimation is unavoidable. By deduction from the decay rate in the first hour in our experiment, the subsurface decay rate of cyanophages ranged from ca. $2.3 \mathrm{~h}^{-1}$ in the summer to ca. $0.8 \mathrm{~h}^{-1}$ in the autumn; this is much higher than the results of Garza \& Suttle (1998). However, if we use

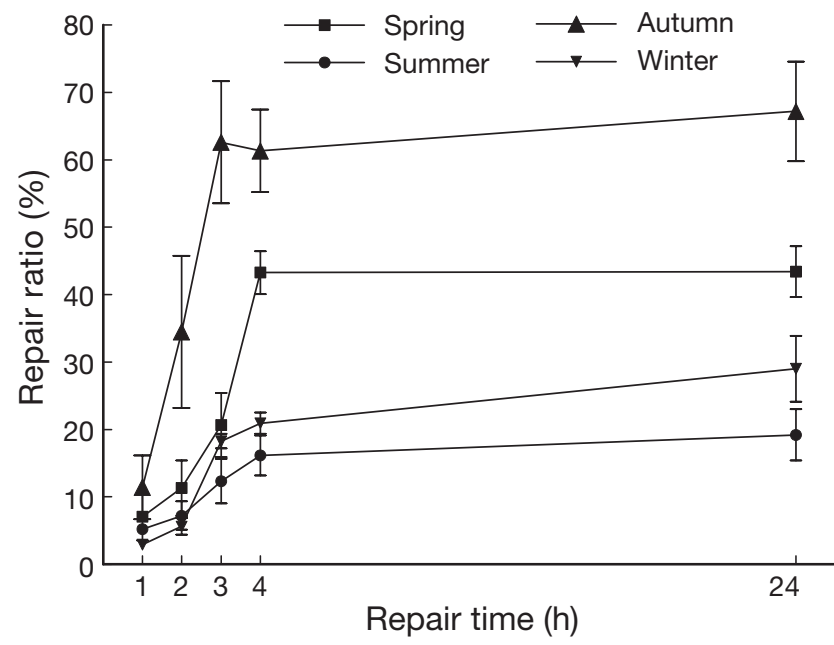

Fig. 2. Repair ratio of the decayed cyanophages that were exposed to solar UV radiation for $3 \mathrm{~h}$ at a depth of $70 \mathrm{~cm}$. The repair ratio of the decayed cyanophages of additional samples is presented in Table 3 
Table 3. Repair ratio (\%; mean $\pm \mathrm{SE}$ ) of the decayed cyanophages on sampling days in all seasons. ${ }^{*}$ Maximum repair ratio observed for each sample

\begin{tabular}{|c|c|c|c|c|c|c|}
\hline $\begin{array}{l}\text { Sunlight } \\
\text { exposure } \\
\text { time (h) }\end{array}$ & $\begin{array}{l}\text { Water } \\
\text { depth } \\
(\mathrm{cm})\end{array}$ & $1 \mathrm{~h}$ & $2 \mathrm{~h}$ & $3 \mathrm{~h}$ & $4 \mathrm{~h}$ & $24 \mathrm{~h}$ \\
\hline \multicolumn{7}{|l|}{ Spring } \\
\hline 3 & 20 & $4.0 \pm 0$ & $4.0 \pm 3.6$ & $20.0 \pm 5.8$ & $16.0 \pm 2.5$ & $28.0 \pm 4.1^{*}$ \\
\hline 3 & 70 & $7.1 \pm 3.5$ & $11.3 \pm 4.1$ & $20.7 \pm 4.8$ & $43.3 \pm 3.2$ & $43.5 \pm 3.8^{*}$ \\
\hline 3 & 120 & $24 \pm 9.6$ & $33.1 \pm 14.1$ & $25.1 \pm 4.3$ & $45.6 \pm 11.3$ & $52.0 \pm 11.7^{*}$ \\
\hline 6 & 20 & $6.7 \pm 1.4$ & $11.0 \pm 1.9$ & $18.1 \pm 2.7$ & $27.0 \pm 1.5$ & $39.7 \pm 1.7^{*}$ \\
\hline 6 & 70 & $5.1 \pm 1.1$ & $11.7 \pm 2.8$ & $22.6 \pm 2.5$ & $30.1 \pm 1.9$ & $36.2 \pm 2.5^{*}$ \\
\hline 6 & 120 & $6.6 \pm 1.9$ & $11.3 \pm 2.0$ & $21.3 \pm 1.9$ & $32.7 \pm 2.3^{*}$ & $46.9 \pm 2.5^{*}$ \\
\hline 9 & 20 & $4.8 \pm 0.9$ & $5.1 \pm 1.6$ & $7.4 \pm 1.6$ & $8.2 \pm 2.6^{*}$ & $6.3 \pm 1.4$ \\
\hline 9 & 70 & $8.6 \pm 1.1$ & $6.9 \pm 1.5$ & $7.5 \pm 1.1$ & $9.6 \pm 1.9$ & $14.5 \pm 3.2^{*}$ \\
\hline 9 & 120 & $18.8 \pm 2.8$ & $19.6 \pm 2.5$ & $31.3 \pm 3.6$ & $33.6 \pm 3.8$ & $37.7 \pm 3.5^{*}$ \\
\hline \multicolumn{7}{|l|}{ Summer } \\
\hline 3 & 20 & $2.4 \pm 0.7$ & $5.6 \pm 1.7$ & $6.4 \pm 1.7$ & $11.2 \pm 0.6^{*}$ & $9.0 \pm 1.6$ \\
\hline 3 & 70 & $5.3 \pm 0.7$ & $7.3 \pm 2.1$ & $12.4 \pm 3.3$ & $16.2 \pm 3.0$ & $19.2 \pm 3.8^{*}$ \\
\hline 3 & 120 & $7.5 \pm 5.1$ & $9.0 \pm 4.9$ & $9.7 \pm 1.7$ & $12.6 \pm 3.1^{*}$ & $10.1 \pm 2.0$ \\
\hline 6 & 20 & $3.8 \pm 1.2$ & $3.5 \pm 1.6$ & $5.4 \pm 0.8$ & $6.0 \pm 1.7$ & $7.4 \pm 2.2^{*}$ \\
\hline 6 & 70 & $6.0 \pm 1.3$ & $7.1 \pm 4.1$ & $17.3 \pm 2.4$ & $16.3 \pm 2.0$ & $20.0 \pm 2.5^{*}$ \\
\hline 6 & 120 & $6.0 \pm 3.9$ & $15.5 \pm 7.2$ & $27.9 \pm 2.9$ & $28.3 \pm 2.9^{*}$ & $27.8 \pm 2.9$ \\
\hline 9 & 20 & $3.5 \pm 0.4$ & $3.6 \pm 0.9$ & $6.0 \pm 1.6$ & $7.5 \pm 0.7$ & $10.3 \pm 1.2^{*}$ \\
\hline 9 & 70 & $19.3 \pm 1.5$ & $20.6 \pm 2.8$ & $24.9 \pm 2.1$ & $28.5 \pm 1.7$ & $29.2 \pm 1.6^{*}$ \\
\hline 9 & 120 & $9.4 \pm 3.0$ & $13.2 \pm 4.5$ & $18.6 \pm 2.3$ & $24.0 \pm 0.7^{*}$ & $23.9 \pm 4.6$ \\
\hline \multicolumn{7}{|l|}{ Autumn } \\
\hline 3 & 20 & $20.0 \pm 6.7$ & $34.6 \pm 5.3$ & $50.8 \pm 1.3$ & $55.2 \pm 3.1$ & $60.8 \pm 4.9^{*}$ \\
\hline 3 & 70 & $11.4 \pm 4.8$ & $34.5 \pm 11.2$ & $62.6 \pm 9.1$ & $61.4 \pm 6.1$ & $67.8 \pm 7.4^{*}$ \\
\hline 3 & 120 & $10.6 \pm 2.8$ & $20.6 \pm 7.9$ & $41.1 \pm 9.7$ & $40.0 \pm 10.0^{*}$ & $35.6 \pm 16.5$ \\
\hline 6 & 20 & $2.7 \pm 2.8$ & $5.4 \pm 3.9$ & $16.5 \pm 1.9$ & $23.8 \pm 2.3$ & $26.4 \pm 1.8^{*}$ \\
\hline 6 & 70 & $3.9 \pm 1.3$ & $14.0 \pm 0.8$ & $23.3 \pm 0.8$ & $27.9 \pm 3.1$ & $51.2 \pm 5.3^{*}$ \\
\hline 6 & 120 & $12.3 \pm 7.5$ & $8.2 \pm 3.6$ & $18.7 \pm 7.2$ & $36.6 \pm 2.2$ & $44.9 \pm 6.0^{*}$ \\
\hline 9 & 20 & $2.7 \pm 2.8$ & $5.4 \pm 3.9$ & $16.5 \pm 1.9$ & $23.8 \pm 2.3$ & $26.4 \pm 1.8^{*}$ \\
\hline 9 & 70 & $3.9 \pm 1.3$ & $14.0 \pm 0.8$ & $23.3 \pm 0.8$ & $27.9 \pm 3.1$ & $51.2 \pm 5.3^{*}$ \\
\hline 9 & 120 & $12.3 \pm 7.5$ & $8.2 \pm 3.6$ & $18.7 \pm 7.2$ & $36.6 \pm 2.2$ & $44.9 \pm 6.0^{*}$ \\
\hline \multicolumn{7}{|l|}{ Winter } \\
\hline 3 & 20 & $1.2 \pm 0.5$ & $4.9 \pm 1.2$ & $10.2 \pm 0.9$ & $13.6 \pm 0.3$ & $22.9 \pm 0.6^{*}$ \\
\hline 3 & 70 & $3.0 \pm 0.7$ & $5.6 \pm 1.2$ & $18.3 \pm 1.1$ & $21.0 \pm 1.6$ & $29.0 \pm 4.8^{*}$ \\
\hline 3 & 120 & $1.1 \pm 0.6$ & $3.4 \pm 1.0$ & $10.9 \pm 2.9$ & $14.8 \pm 3.3$ & $20.7 \pm 5.3^{*}$ \\
\hline 6 & 20 & $2.8 \pm 0.6$ & $16.4 \pm 1.3$ & $21.1 \pm 1.1$ & $33.8 \pm 1.7$ & $33.8 \pm 3.4^{*}$ \\
\hline 6 & 70 & $8.5 \pm 3.1$ & $20.9 \pm 1.1$ & $25.9 \pm 0.7$ & $32.8 \pm 1.8$ & $43.8 \pm 1.5^{*}$ \\
\hline 6 & 120 & $5.3 \pm 2.2$ & $21.4 \pm 2.2$ & $33.1 \pm 1.8$ & $35.2 \pm 4.2$ & $37.7 \pm 3.1^{*}$ \\
\hline 7.5 & 20 & $7.1 \pm 0.3$ & $13.3 \pm 0.3$ & $37.8 \pm 0.6$ & $38.7 \pm 0.9$ & $39.7 \pm 0.7^{*}$ \\
\hline 7.5 & 70 & $6.3 \pm 2.2$ & $15.6 \pm 1.9$ & $28.7 \pm 3.3$ & $40.0 \pm 1.0$ & $44.9 \pm 2.9^{*}$ \\
\hline 7.5 & 120 & $9.3 \pm 2.7$ & $12.2 \pm 0.5$ & $41.3 \pm 3.5$ & $48.1 \pm 1.3$ & $53.9 \pm 3.5^{*}$ \\
\hline
\end{tabular}

(Garza \& Suttle 1998), or UV-sensitive organisms may grow and divide quickly to 'dilute' the phototoxicity (Hader \& Sinha 2005). Active mechanisms include photoreactivation, excision repair, recombination repair, and mutagenesis, of which photoreactivation is the easiest and the most efficient (Kellogg \& Paul 2002, Sinha \& Hader 2002). Photolyase, the enzyme that catalyses the reaction, represents one of the simplest and most classical systems that exists in various organisms, including cyanobacteria (Sancar 1996). Although some viruses can encode their own photolyase, most viruses (phages) rely on the repair system of their host (Shaffer \& Jacobsen 1999, Viswanathan et al. 2001). Host-mediated photoreactivation can restore the infectivity of solar-damaged virus by as much as 21 to $78 \%$ daily (Weinbauer et al. 1997, Wommack \& Colwell 2000). In our experiment, the repair ratio reached as high as $59 \%$ in $24 \mathrm{~h}$. However, this may be an overestimation as the in situ environmental conditions hardly meet the requirements of the host cells for photoreactivation (Wilhelm et al. 1998, Kadavy et al. 2000). It has been reported that the repair ratio for marine viral communities decreased from $50 \%$ in coastal eutrophic areas to $25 \%$ in offshore dystrophic areas (Weinbauer et al. 1997). Moreover, we also note that $4 \mathrm{~h}$ is sufficient to reach the maximum repair ratios in most cases, indicating that rapid repair may be a strategy to balance the fast decay observed under field conditions. the decay rate of the entire daytime ( $9 \mathrm{~h})$ in subsurface water, the result ranges from ca. $0.26 \mathrm{~h}^{-1}$ in the summer to ca. $0.08 \mathrm{~h}^{-1}$ in the autumn, which is within the range of Garza \& Suttle's (1998) results.

Microorganisms can protect themselves from UV damage by developing passive and active protection mechanisms to minimize or repair the phototoxic DNA damage. The passive mechanism is that viral DNA may adapt to the local UV radiation by natural selection, e.g. native virus isolates degrade more slowly in full sunlight than non-native marine bacteriophages
Acknowledgements. This study was financially supported by the NSFC (National Science Foundation of China, Nos. 30470344 and 30370062), and by a special fund from the president of the Chinese Academy of Sciences (No. 892).

\section{LITERATURE CITED}

Bratbak G, Heldal M, Norland S, Thingstad TF (1990) Viruses as partners in spring bloom microbial trophodynamics. Appl Environ Microbiol 56:1400-1405

Cottrell MT, Suttle CA (1995) Dynamics of a lytic virus infecting the photosynthetic marine picoflagellate Micromonas pusilla. Limnol Oceanogr 40:730-739 
Fox JA, Booth SJ, Martin EL (1976) Cyanophage SM-2: a new blue-green algal virus. Virology 73:557-560

Fuhrman JA (1999) Marine viruses and their biogeochemical and ecological effects. Nature 399:541-548

Garza DR, Suttle CA (1998) The effect of cyanophages on the mortality of Synechococcus spp. and selection for UV resistant viral communities. Microb Ecol 36:281-292

Guo Y, Cheng K, Zhao Y, Wang J, Wang C, Shi Z, Liu Y (2003) The distribution and infectivity of cyanophage and other algae-lysing factors in freshwater. China Environ Sci 23:167-170 (in Chinese with English abstract)

Hader DP, Sinha RP (2005) Solar ultraviolet radiation-induced DNA damage in aquatic organisms: potential environmental impact. Mutat Res 571:221-233

Jacquet SB (2003) Effects of ultraviolet radiation on marine virus-phytoplankton interactions. FEMS Microbiol Ecol 44:279-289

Kadavy DR, Shaffer JJ, Lott SE, Wolf TA and 5 others (2000) Influence of infected cell growth state on bacteriophage reactivation levels. Appl Environ Microbiol 66:5206-5212

Kellogg CA, Paul JH (2002) Degree of ultraviolet radiation damage and repair capabilities are related to $\mathrm{G}+\mathrm{C}$ content in marine vibriophages. Aquat Microb Ecol 27:13-20

Noble RT, Fuhrman JA (1997) Virus decay and its causes in coastal waters. Appl Environ Microbiol 63:77-83

Noble RT, Fuhrman JA (2000) Rapid virus production and removal as measured with fluorescently labeled viruses as tracers. Appl Environ Microbiol 66:3790-3797

Regan JD, Carrier WL, Gucinski H, Olla BL, Yoshida H, Fujimura RK, Wicklund RI (1992) DNA as a solar dosimeter in the ocean. Photochem Photobiol 56:35-42

Richard W (1988) Methods in enzymology: cyanobacteria, Vol 167. Academic Press, San Diego, CA

Sancar A (1996) No 'end of history' for photolyases. Science $272: 48-49$

Editorial responsibility: Curtis Suttle, Vancouver, British Columbia, Canada
Shaffer JJ, Jacobsen LM (1999) Characterization of Pseudomonas aeruginosa bacteriophage UNL-1, a bacterial virus with a novel UV-A-inducible DNA damage reactivation phenotype. Appl Environ Microbiol 65:2606-2613

Sinha RP, Hader DP (2002) UV-induced DNA damage and repair: a review. Photochem Photobiol Sci 1:225-236

Suttle CA (1993) Enumeration and isolation of viruses. In: Kemp PF (ed) Handbook of method in aquatic microbial ecology. Lewis Publishers, Boca Raton, FL

Tucker S, Pollard P (2005) Identification of cyanophage Ma-LBP and infection of the cyanobacterium Microcystis aeruginosa from an Australian subtropical lake by the virus. Appl Environ Microbiol 71:629-635

Viswanathan S, William MS, Deoki NT (2001) Fowlpox virus encodes a novel DNA repair enzyme, CPD-photolyase, that restores infectivity of UV light-damaged virus. J Virol 75:1681-1688

Weinbauer MG (2004) Ecology of prokaryotic viruses. FEMS Microbiol Rev 28:127-181

Weinbauer MG, Wilhelm SW, Suttle CA, Garza DR (1997) Photoreactivation compensates for UV damage and restores infectivity to natural marine virus communities. Appl Environ Microbiol 63:2200-2205

Wilhelm SW, Weinbauer MG, Suttle CA, Jeffrey WH (1998) The role of sunlight in the removal and repair of viruses in the sea. Limnol Oceanogr 43:586-598

Wommack KE, Colwell RR (2000) Virioplankton: viruses in aquatic ecosystems. Microbiol Mol Biol Rev 64:69-114

Wommack KE, Russell TM, Terri AC, Rita R (1996) Effects of sunlight on bacteriophage viability and structure. Appl Environ Microbiol 62:1336-1341

Zhao Y, Cheng K, Shi Z, Guo Y, Zhu H, Zhang J, Liu Y (2002) The first report of the isolation and identification of cyanophage in P.R. China. Prog Nat Sci 12:923-927 (in Chinese)

Submitted: July 26, 2006; Accepted: April 17, 2007

Proofs received from author(s): June 12, 2007 